\title{
CARBON IN SOIL IN DIFFERENT PHISIONOMIES OF CAATINGA IN PARAÍBA, BRAZIL
}

\author{
Bruna Vieira de Souza ${ }^{1}$, Patrícia Carneiro Souto ${ }^{2}$, Jacob Silva Souto ${ }^{3}$, Francisco das Chagas Vieira Sales ${ }^{4 *}$, \\ Carlos Magno Pereira de Souza Junior ${ }^{5}$
}

${ }^{1}$ Advice and Management in Nature Studies, Human Development and Agroecology - souzavieirab@gmail.com

${ }^{2}$ Federal University of Campina Grande - UFCG - Patos Campus - pcarneirosouto@yahoo.com.br ${ }^{2}$, jacob_souto@yahoo.com.br ${ }^{3}$, franciscoef@yahoo.com.br ${ }^{4 *}$, carlosmpsj@gmail.com ${ }^{5}$

Received for publication: 25/01/2018 - Accepted for publication: 20/08/2018

\begin{abstract}
The devastation of the caatinga vegetation by disorderly exploration has led to the intensification of carbon release, modifying the capacity of soils to stock this element. The study aimed to determine the stock of organic carbon in Caatinga areas. Which it was conducted in the city of Várzea, state of Paraíba in Brazil, in four areas with vegetation in different successional stages. Soil samples were collected to determine the levels of carbon in 04 depths $(0-5 \mathrm{~cm}, 5-10 \mathrm{~cm}, 10-15 \mathrm{~cm}$ and $15-20 \mathrm{~cm})$ in two seasons of the year. The averages of the carbon were compared by Tukey test. The amounts of carbon in the soil showed significant differences in the factors of time, study area and depth. In the dry season, the quantities and the carbon stock were higher than those registered in the rainy season in all the studied areas, being Late Secondary Caatinga and Preserved Caatinga the areas with the highest values. The Late Secondary Caatinga had the highest carbon stock (33.01 $\left.\mathrm{Mg} \mathrm{ha}^{-1}\right)$ in the rainy season. On the other hand, in the dry season, the highest carbon stock was in Preserved Caatinga (49.77 $\mathrm{Mg} \mathrm{ha}^{-1}$ ). Larger amounts of organic carbon were found in the area of Preserved Caatinga, being the higher carbon concentrations recorded in the dry season.

Keywords: Tropical dry Forest, carbon storage, succession of caatinga.
\end{abstract}

\section{Resumo}

Carbono no solo em diferentes fisionomias de caatinga na Paraíba, Brasil. A devastação da vegetação da caatinga pela exploração desordenada tem levado à intensificação da liberação do carbono, modificando a capacidade dos solos de estocar esse elemento. O estudo objetivou determinar o estoque de carbono orgânico em diferentes fisionomias da Caatinga. O qual foi desenvolvido no município de Várzea-PB em quatro áreas com vegetação em diferentes estágios sucessionais. Foram coletadas, então, amostras de solo para determinação de teores de Carbono em 04 profundidades $(0-5 \mathrm{~cm}, 5-10 \mathrm{~cm}, 10-15 \mathrm{~cm}$ e 15-20 cm) em duas épocas. As médias foram comparadas pelo teste Tukey. As quantidades de carbono no solo apresentaram diferenças significativas quanto aos fatores época, área de estudo e profundidade. Na época seca as quantidades e estoque de carbono foram superiores às registradas na época chuvosa em todas as áreas estudadas, tendo as áreas de Caatinga Secundária Tardia e Caatinga Preservada registrado os maiores valores. A Caatinga Secundária Tardia apresentou o maior estoque de carbono $\left(33,01 \mathrm{Mg} \mathrm{ha}^{-1}\right)$ na época chuvosa. Já na época seca, o maior estoque ocorreu na Caatinga Preservada (49,77 $\left.\mathrm{Mg} \mathrm{ha}^{-1}\right)$. Os maiores estoques de carbono orgânico foram encontrados na área de Caatinga Preservada com os maiores valores registrados na época seca, revelando a importância da conservação da vegetação da caatinga para manter a eficiência do processo assimilatório e acumulador de carbono, principalmente na época seca.

Palavras-chave: Florestas Secas Tropicais, armazenamento de carbono, sucessão da caatinga.

\section{INTRODUCTION}

Anthropic activities have provoked a series of alterations in the landscapes of the bioma Caatinga, mainly by the degradation of the vegetal covering, the incorrect use of the ground, the deforestations and forest fires, these factors contribute significantly in the emission of gases in the atmosphere.

In accordance with Silva et al. (2008), from the decade of 1980 the integrity of the planet started to be threatened, in which prominent questions of climatic changes and global heating emerged. Almeida et al. (2010) suggest the need to study and employ strategies to reduce the concentration of greenhouse gases (GHGs) in the atmosphere, as global concern is growing around the concentration of carbon dioxide $\left(\mathrm{CO}_{2}\right)$, which one increased by approximately $35 \%$ since the industrial revolution.

The Caatinga can be a significant deposit of carbon, however, it is still poorly known and exploited for this purpose, due to its recurrent climatic and vegetative seasonalities that have its representativeness in the reduction of carbon in the atmosphere. Mainly in what concerns the managed areas, the management regime with the regrowth conduction intensifies the capture of $\mathrm{CO}_{2}$ in the photosynthetic process for tree growth, presenting 
itself as a carbon sink strategy. Lal (2002) still points out that as in plants, the soil also stores carbon, being an important factor in the understanding of mitigation of GHG emissions.

Organic matter is an important component in any terrestrial ecosystem, being responsible for the stability of the structure, infiltration and retention of water, aeration and microbial biomass activities, making the soil dynamic in carbon storage, facilitating, then, the storage of three times more carbon than the atmosphere (RIOS et al., 2006). Thus, in the soil, carbon is divided into inorganic and organic forms. The organic as a constituent of matter or substances that have elements of carbon and hydrogen in their molecules, and may also contain nitrogen, sulfur, phosphorus and other elements in its structure; and the inorganic is found in the source material and limestone rocks (ALCÂNTARA NETO et al., 2011).

In the present conditions of use and disordered occupation of the soil that occurs in the caatinga by the reduction of the vegetal cover and exposure of the soil to the erosive agents, which, in turn, causes the loss of nutrients, it is necessary to carry out studies on the inventory estimates of carbon, with the purpose of subsidizing information for planning and execution of forest resources management, assisting in the calculation of greenhouse gas emissions, which is due to the combustion and decomposition of organic matter in anthropic and preserved systems (SILVEIRA et al., 2008). Nunes et al. (2009) verified changes in organic carbon in anthropogenic areas, showing a reduction of $10 \%$ in these areas when compared to preserved areas, considering, therefore, the organic carbon stock as a promising attribute for the evaluation of soil quality. Having all that in mind, the aim of this work is to estimate the amount and the stock of organic carbon in the soil of the Caatinga area under different phytophysiognomies.

\section{MATERIAL AND METHODS}

\section{Areas of study}

The study was developed at Cachoeira in São Porfírio Farm $\left(06^{\circ} 48^{\prime} 32,1^{\prime \prime S}, 36^{\circ} 57^{\prime} 17,4^{\prime \prime}\right.$ W), which occupies an area of 58 hectares situated in the municipality of Várzea-PB, located in the mesoregion of "Sertão Paraibano", with an altitude of $271 \mathrm{~m}$. According to the Köppen (ALVARES et al., 2014) classification, the climate of the region falls into the type BSh, semiarid, with an annual average temperature above $25^{\circ} \mathrm{C}$ and annual average rainfall less than $800 \mathrm{~mm}_{\text {year }}{ }^{-1}$ with irregular rains.

For the accomplishment of the study, it was selected four areas of $3000 \mathrm{~m}^{2}$, with vegetation in different successional stages:

$\rightarrow$ Area 1 - Native Pasture (NP): Area with herbaceous and shrubby vegetation devoid of arboreal vegetation, predominating panasco grass (Aristida setifolia Kunth.) and some shrubs such as the "malva branca" (Sida cordifolia L.), "alfazema" plants (Hyptis suaveolens L. Poit) and "pinhão" plants (Jathropha sp.). The area was surrounded in order to avoid the presence of animals, located under the coordinates $06^{\circ} 48^{\prime} 18.5^{\prime \prime} \mathrm{S}$, $36^{\circ} 566^{\prime} 58.9^{\prime \prime} \mathrm{W}$.

$\rightarrow$ Area 2 - Initial Secondary Caatinga (ISC): Area with presence of shrub-tree vegetation with approximately 10 years of age, located under the coordinates $6^{\circ} 48^{\prime} 24.8^{\prime \prime} \mathrm{S} ; 36^{\circ} 57^{\prime} 10.6^{\circ} \mathrm{W}$. In this area the species of highest occurrence are "marmeleiro" plants (Croton sonderianus Muell. Arg.), "jurema preta" plants (Mimosa tenuiflora (Willd.) Poir.), "faveleira" plants (Cnidoscullus phyllacanthus Pax et K. Hoffm), "catingueira" plants (Poincianella pyramidalis (Tul.) LP Queiroz), "malva branca" plants (Sida cordifolia) and "alfazema" plants (Hyptis suaveolens L. Poit.). The arboreal vegetation is composed of small and spaced individuals, with clearings occupied by the herbaceous stratum.

$\rightarrow$ Area 3 - Late Secondary Caatinga (LSC): Area with 20 to 25 year-old arboreal-shrub vegetation, located under the coordinates $6^{\circ} 48^{\prime} 22.3^{\prime \prime S}, 36^{\circ} 57^{\prime} 04.1^{\prime \prime} \mathrm{W}$. In the area, there are specimens of "jurema preta" species (Mimosa tenuiflora), "faveleira" plants (Cnidoscullus phyllacanthus), "catingueira" plants (Poincianella pyramidalis). The arboreal vegetation is composed of small and spaced individuals, with clearings occupied by the herbaceous stratum.

$\rightarrow$ Area 4 - Preserved/climax Caatinga (PC): vegetation approximately 50 years old, located under the coordinates $6^{\circ} 48^{\prime} 32.5^{\prime \prime} \mathrm{S}, 36^{\circ} 57^{\prime} 09.0^{\prime \prime} \mathrm{W}$, where individuals as "catingueira" plants (Poincianella pyramidalis), "faveleira" plants (Cnidoscullus phyllacanthus) and "jurema preta" plants (Mimosa tenuiflora) are found and there is possible presence of herbaceous species. This area is characterized by the presence of individuals of high, medium and small size, with most of their treetops touching, shading the soil with consequent reduction of herbaceous stratum.

The predominant soils in the region are associations of Luvisols and Litholic Neosols (EMBRAPA, 2013), with rock outcrops and topography with subtle undulating variations. The chemical characterization of the soil of the experimental areas can be visualized in table 1 . 
Table 1. Chemical characteristics of the soil of the areas studied.

Tabela 1. Características químicas do solo das áreas estudadas.

\begin{tabular}{|c|c|c|c|c|c|c|c|c|c|c|c|}
\hline \multirow{2}{*}{ Areas } & $\mathrm{pH}$ & $\mathrm{P}$ & $\mathrm{Al}^{3+}$ & $\mathrm{H}+\mathrm{Al}$ & $\mathrm{K}^{+}$ & $\mathrm{Ca}^{+2}$ & $\mathrm{Mg}^{+2}$ & SB & CTC & $\mathrm{V} \%$ & \multirow{2}{*}{$\begin{array}{c}\mathrm{S} \\
\mathrm{mg} \mathrm{dm}{ }^{-3}\end{array}$} \\
\hline & $\mathrm{CaCl}_{2}$ & $\mathrm{mg} \mathrm{dm}{ }^{-3}$ & \multicolumn{8}{|c|}{$------------\mathrm{mmol}_{\mathrm{c}} \mathrm{dm}^{-3}{ }_{----------}$} & \\
\hline Native Pasture & 4.9 & 4.0 & 1.0 & 17.0 & 2.3 & 10.0 & 3.0 & 15.0 & 33.0 & 47 & 3.0 \\
\hline Initial Secondary Caatinga & 5.3 & 3.0 & 1.0 & 15.0 & 3.8 & 16.0 & 5.0 & 24.0 & 39.0 & 62 & 3.0 \\
\hline Late Secondary Caatinga & 5.0 & 3.0 & 1.0 & 18.0 & 2.3 & 14.0 & 4.0 & 20.0 & 38.0 & 53 & 3.0 \\
\hline Preserved Caatinga & 5.4 & 4.0 & 1.0 & 15.0 & 1.6 & 13.0 & 5.0 & 20.0 & 34.0 & 57 & 3.0 \\
\hline
\end{tabular}

In each of the different successional stages, three portions of $20 \mathrm{~m} \times 50 \mathrm{~m}$ were installed, in which the soil samples were collected for carbon quantification. The collections were done in the rainy season (April/2010) and in the dry season (October/2010).

\section{Collection of soil samples}

Soil collection for the determination of apparent density and quantification of organic carbon in the soil was performed in the central part of the areas, in four depths $(0-5 \mathrm{~cm}, 5-10 \mathrm{~cm}, 10-15 \mathrm{~cm}$ and $15-20 \mathrm{~cm})$, composing four soil samples per portion, totaling 12 samples for rainy season and 12 for dry season. The depths were determined by the virtue of rocky material and by representing the common depth of roots occupation of most of the plants present in the environment. The samples for determination of apparent density of the soil were taken with the support of metal rings at the above mentioned depths.

The samples were duly identified and sent to the Laboratory of Mineral Nutrition of Plants of the Federal University of Campina Grande - LABNUT/UFCG in Patos (PB), which were individually weighed, thus obtaining the weight of wet mass. Subsequently, they were placed in a drying oven at $105^{\circ} \mathrm{C}$ for 72 hours and then weighed to determine the weight of dry mass.

- Soil humidity was determined from equation (1):

$U S=\frac{P U-P S}{P S} \times 100$

in which: US = humidity of soil sample in percentage (\%); PU = weight of wet mass in the sample (g); PS = weight of dry mass in the sample (g);

- Volume of the cylinder was calculated by equation (2):

$V=\frac{\pi \cdot d^{2}}{4} \cdot h$

in which: $\mathrm{V}=$ cylinder volume $\left(\mathrm{cm}^{3}\right) ; \mathrm{d}=$ internal diameter $($ in $\mathrm{cm}) ; \mathrm{h}=$ height $($ in $\mathrm{cm})$.

- The soil density was obtained by equation (3):

$D=\frac{P S}{V S}$

in which: $\mathrm{D}=$ assumed apparent density $\left(\mathrm{g} \mathrm{cm}^{3}\right)$; PS = dry mass in the sample $(\mathrm{g})$ determined in the laboratory; $\mathrm{VS}=$ sample volume $\left(\mathrm{cm}^{3}\right)$; (calculated by the cylinder volume formula).

The soil samples collected for quantification of the organic carbon at each depth were taken in small trenches; the soil was collected with the aid of a spatula and then stored in plastic bags. The samples were air dried and then sieved in a $2.0 \mathrm{~mm}$ mesh and sent to the soil and water laboratory - LASAG/UFCG in Patos (PB) for analysis.

The methodology used to estimate the soil carbon stock was based on Gatto et al. (2010), in which the total organic carbon stock is the product of the carbon content by its density and depth of excavation, according to equation (4). Thus, the total carbon stock along the profile was obtained by summing the average stock at each depth, being the values expressed in $\mathrm{Mg} \mathrm{had}^{-1}$.

$$
\text { Est }_{\text {Total }} C=C \cdot D \cdot P
$$

in which: Est Total $\mathrm{C}=$ total carbon Stock $\left(\mathrm{Mg} \mathrm{ha}^{1}\right) ; \mathrm{C}=$ average carbon content $\left(\mathrm{g} \mathrm{dm}^{-3}\right) ; \mathrm{D}=\operatorname{soil}$ density $\left(\mathrm{g} \mathrm{cm}^{-3}\right)$; $\mathrm{P}=\operatorname{digging}$ depth $(\mathrm{cm})$ 


\section{Statistical analysis of the data}

An analysis of variance was performed for the carbon contents between the four successional stages in the soil compartment at two seasons of the year. The analysis had a factorial arrangement $2 \times 4 \times 4$ ( 2 seasons, 4 areas and 4 depths), with 3 replicates per treatment. For the data of carbon quantity and carbon stock in the soil in each area surveyed, the average test was applied to evaluate the existence of difference between the depths. The significance level of $5 \%$ of the Tukey test was used to compare the average values of carbon. Statistical analyzes were performed with the assistance of the statistical software ASSISTAT Version 7.5 beta (SILVA; AZEVEDO, 2012).

\section{RESULTS}

It was verified in the analysis of variance (Table 2) that the data referring to the amounts of carbon in the soil presented significant differences regarding the factors of time, area of study and depth. Therefore, the discussion of soil carbon content data was performed for each verification factor independently.

Table 2. Analysis of variance of the levels of soil carbon $\left(\mathrm{Mg} \mathrm{ha}^{-1}\right)$ and their interactions.

Tabela 2. Análise de variância dos teores de carbono no solo $\left(\mathrm{Mg} \mathrm{ha}^{-1}\right)$ e suas interações.

\begin{tabular}{lllll}
\hline F.V. & G.L. & S.Q. & Q.M. & F \\
\hline Season (F1) & 1 & 656.73113 & 656.73113 & $39.4363 *$ \\
Area (F2) & 3 & 508.73144 & 169.57715 & $10.1830 *$ \\
Depth (F3) & 3 & 502.37143 & 167.45714 & $10.0557 *$ \\
Int. F1xF2 & 3 & 59.82658 & 19.94219 & $0.1975 \mathrm{~ns}$ \\
Int. F1xF3 & 3 & 40.92057 & 13.64019 & $0.8191 \mathrm{~ns}$ \\
Int. F2xF3 & 9 & 105.38018 & 11.70891 & $0.7031 \mathrm{~ns}$ \\
Int.F1xF2xF3 & 9 & 127.85941 & 14.20660 & $0.8531 \mathrm{~ns}$ \\
Treatments & 31 & 2001.82073 & 64.57486 & $3.8777 *$ \\
Residue & 64 & 1065.78873 & 16.65295 & \\
\hline Total & 95 & 3067.60947 &
\end{tabular}

In relation to the average amounts of soil carbon in the rainy season (Table 3), there was a significant difference between the areas, where in the Late Secondary Caatinga area the highest amount of soil carbon was recorded with $9.00 \mathrm{Mg} \mathrm{ha}^{-1}$.

Table 3. Number and soil carbon average stock $\left(\mathrm{Mg} \mathrm{ha}^{-1}\right)$ in the $0-20 \mathrm{~cm}$ depth in the municipality of Varzea - PB. Tabela 3. Quantidade e estoque médio de carbono no solo $\left(\mathrm{Mg} \mathrm{ha}^{-1}\right)$ na profundidade $0-20 \mathrm{~cm}$ no município de Várzea - PB.

\begin{tabular}{|c|c|c|c|}
\hline Quantity of Carbon & \multicolumn{3}{|c|}{ Season } \\
\hline Areas of study & Rainy ${ }^{\text {ab }}$ & Dry & SMD \\
\hline Native Pasture & $3.72 \mathrm{bB}$ & $8.07 \mathrm{bA}$ & 2.54 \\
\hline Initial Secondary Caatinga & $3.99 \mathrm{bB}$ & $10.31 \mathrm{abA}$ & 3.89 \\
\hline Late Secondary Caatinga & $9.00 \mathrm{aA}$ & $12.13 \mathrm{abA}$ & 3.62 \\
\hline Preserved Caatinga & $7.87 \mathrm{aB}$ & $14.99 \mathrm{aA}$ & 3.89 \\
\hline Significative Minimum Difference (SMD) & 3.80 & 5.94 & \\
\hline Stock of carbono & \multicolumn{3}{|c|}{ Season } \\
\hline Areas of study & Rainy $^{\text {ab }}$ & Dry & SMD \\
\hline Native Pasture & $13.23 \mathrm{bB}$ & $29.50 \mathrm{bA}$ & 9.22 \\
\hline Initial Secondary Caatinga & $14.65 \mathrm{abB}$ & $33.79 \mathrm{abA}$ & 13.71 \\
\hline Late Secondary Caatinga & $33.01 \mathrm{aA}$ & $43.72 \mathrm{abA}$ & 13.38 \\
\hline Preserved Caatinga & $26.99 \mathrm{abB}$ & $49.77 \mathrm{aA}$ & 11.12 \\
\hline Significative Minimum Difference (SMD) & 13.79 & 19.93 & \\
\hline
\end{tabular}

In the dry season (Table 3), the carbon stocks and stocks were higher than those recorded in the rainy season in all studied areas and the highest amounts were recorded in the Late Secondary Caatinga and Preserved Caatinga areas. 
In the native pasture area (Figure 1), it was observed that in the rainy season there was no significant difference in the average carbon contents between the evaluated depths. In the dry season, there was a significant difference in the distribution of carbon contents along the depths, and the highest carbon content was recorded in the soil surface layer $(0-5 \mathrm{~cm})$ with $14.03 \mathrm{Mg} \mathrm{ha}^{-1}$; the other layers had values in the order of $77.86 \mathrm{Mg} \mathrm{ha}^{-1}(5-10$ $\mathrm{cm}), 4.49 \mathrm{Mg} \mathrm{ha}^{-1}(10-15 \mathrm{~cm})$ and $5.89 \mathrm{Mg} \mathrm{ha}^{-1}(15-20 \mathrm{~cm})$ of carbon.

$$
\text { II } 0-05 \mathrm{~cm} \quad \therefore 05-10 \mathrm{~cm} \times 10-15 \mathrm{~cm} \quad=15-20 \mathrm{~cm}
$$

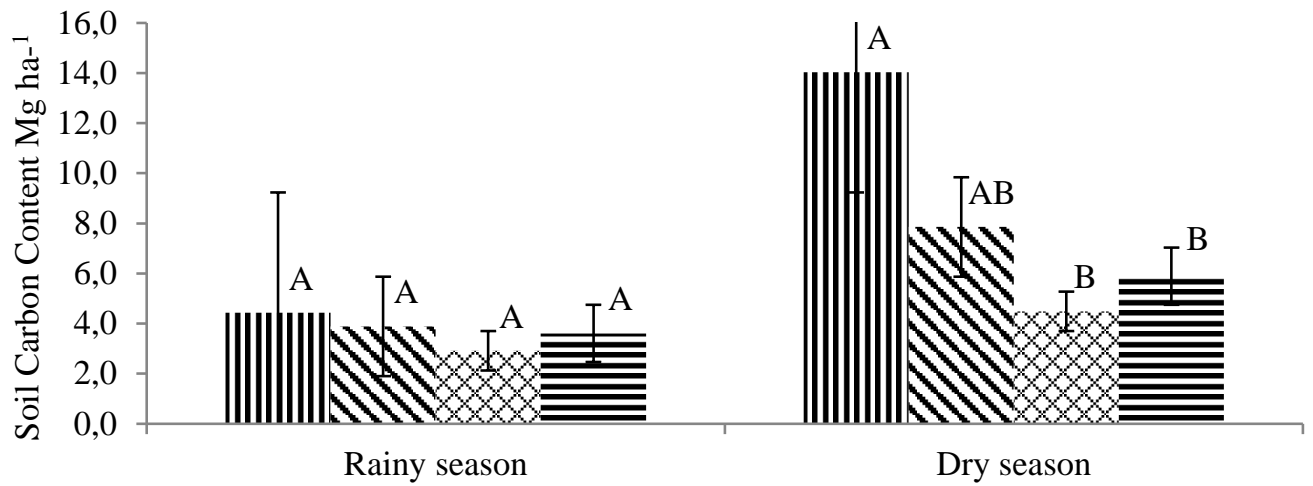

Figure 1. Soil carbon content $\left(\mathrm{Mg} \mathrm{ha}^{-1}\right)$ in native pasture area at different depths during rainy and dry seasons in the municipality of Varzea - PB.

Figura 1. Quantidade de carbono no solo $\left(\mathrm{Mg} \mathrm{ha}^{-1}\right)$ em área de Pasto Nativo em diferentes profundidades nas épocas chuvosa e seca no município de Várzea - PB.

Means followed by the same letter between the depths do not differ statistically from each other by the Tukey test at $5 \%$ probability, as well as the respective standard error bars.

As can be verified (Figures 2 and 3), there was no significant difference in the carbon quantities between soil depths in any of the studied seasons and areas (Native Pasture, Initial Secondary Caatinga, Late Secondary Caatinga, Preserved Caatinga). However, it was noted that the soil surface layer $(0-5 \mathrm{~cm})$ tended to have higher values recorded in the amount of carbon.

$$
\text { II } 0-05 \mathrm{~cm} \quad \times 05-10 \mathrm{~cm} \quad \odot 10-15 \mathrm{~cm} \quad=15-20 \mathrm{~cm}
$$

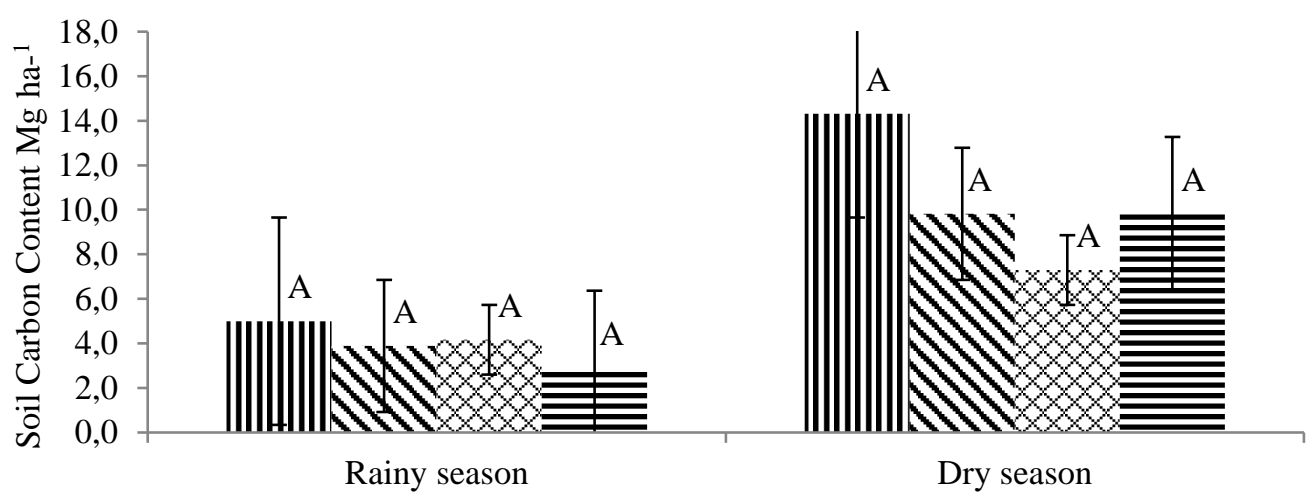

Figure 2. Soil carbon content $\left(\mathrm{Mg} \mathrm{ha}^{-1}\right)$ in Initial Secondary Caatinga area at different depths during rainy and dry seasons in the municipality of Várzea - PB.

Figura 2. Quantidade de Carbono no solo $\left(\mathrm{Mg} \mathrm{ha}^{-1}\right)$ em área de Caatinga Secundária Inicial em diferentes profundidades nas épocas chuvosa e seca no município de Várzea - PB.

Means followed by the same letter between the depths do not differ statistically from each other by the Tukey test at $5 \%$ probability, as well as the respective standard error bars.

It can be seen in figure 3 that the carbon content in the soil in Late Secondary Caatinga in the rainy season decreases with the increase of the depth, in the same way as it was observed in the other areas. As occurred in the 
Early Secondary Caatinga area in the rainy season, the amount of carbon in the Late Secondary Caatinga area tended to be the lowest in the $15-20 \mathrm{~cm}$ layer with $6.32 \mathrm{Mg} \mathrm{ha}^{-1}$, which was $45 \%$ lower than the value recorded in the topsoil $(0-5 \mathrm{~cm})$.

$$
\text { II } 0-05 \mathrm{~cm} \quad \times 05-10 \mathrm{~cm} \quad \vee 10-15 \mathrm{~cm} \quad \equiv 15-20 \mathrm{~cm}
$$

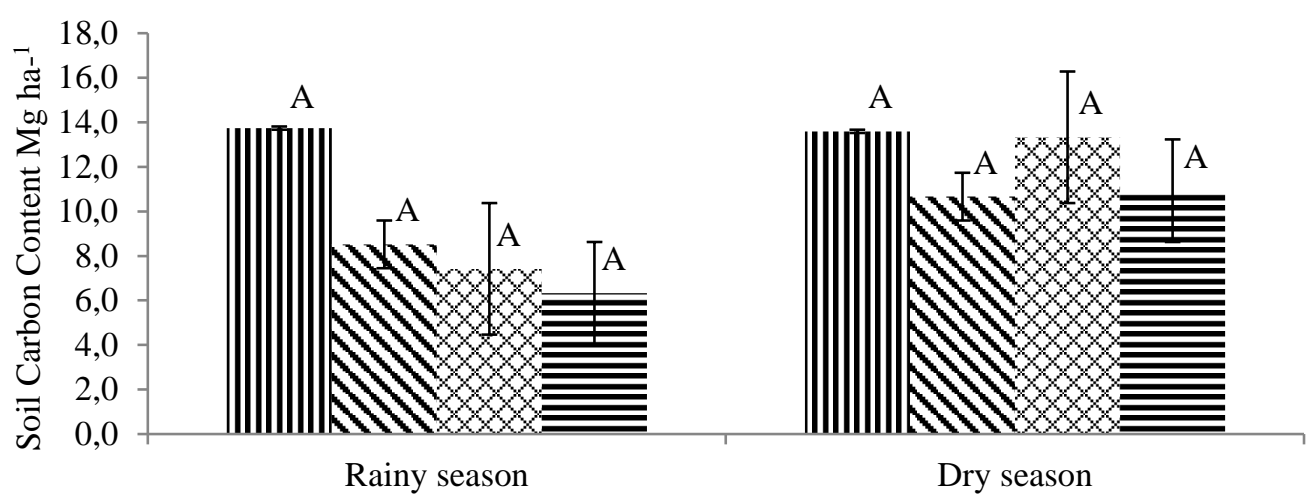

Figure 3. Soil carbon content $\left(\mathrm{Mg} \mathrm{ha}^{-1}\right)$ in late secondary Caatinga area at different depths during rainy and dry seasons in the municipality of Várzea - PB.

Figura 3. Quantidade de Carbono $\left(\mathrm{Mg} \mathrm{ha}^{-1}\right)$ em área de Caatinga Secundária Tardia em diferentes profundidades nas épocas chuvosa e seca no município de Várzea - PB.

Means followed by the same letter between the depths do not differ statistically from each other by the Tukey test at $5 \%$ probability, as well as the respective standard error bars.

In the Preserved Caatinga area there was a significant difference in the amount of carbon in the rainy season between the studied depths (Figure 4); it was observed that in the two seasons the superficial layer of the soil $(0-5 \mathrm{~cm})$ presented the highest amounts of carbon with $13.19 \mathrm{Mg} \mathrm{ha}^{-1}$ for the rainy season and $22.92 \mathrm{Mg} \mathrm{ha}^{-1}$ for the dry season. Also in the rainy season, the lowest amount of carbon was observed in the layer of $5-10 \mathrm{~cm}$ with 5.22 $\mathrm{Mg} \mathrm{ha}^{-1}$ being, however, statistically similar to those obtained in the deeper layers 10-15 $\mathrm{cm}$ with 6.46 $\mathrm{Mg} \mathrm{ha}^{-1}$ and $15-20 \mathrm{~cm}$ with $5.59 \mathrm{Mg} \mathrm{ha}^{-1}$. In relation to the dry season, it can be seen in Figure 4 that there were no significant differences, however, the $0-5 \mathrm{~cm}$ layer with $22.92 \mathrm{Mg} \mathrm{ha}^{-1}$ tended to have the greatest amount of carbon.

$$
\text { II } 0-05 \mathrm{~cm} \quad \ 05-10 \mathrm{~cm} \quad \times 10-15 \mathrm{~cm} \quad=15-20 \mathrm{~cm}
$$

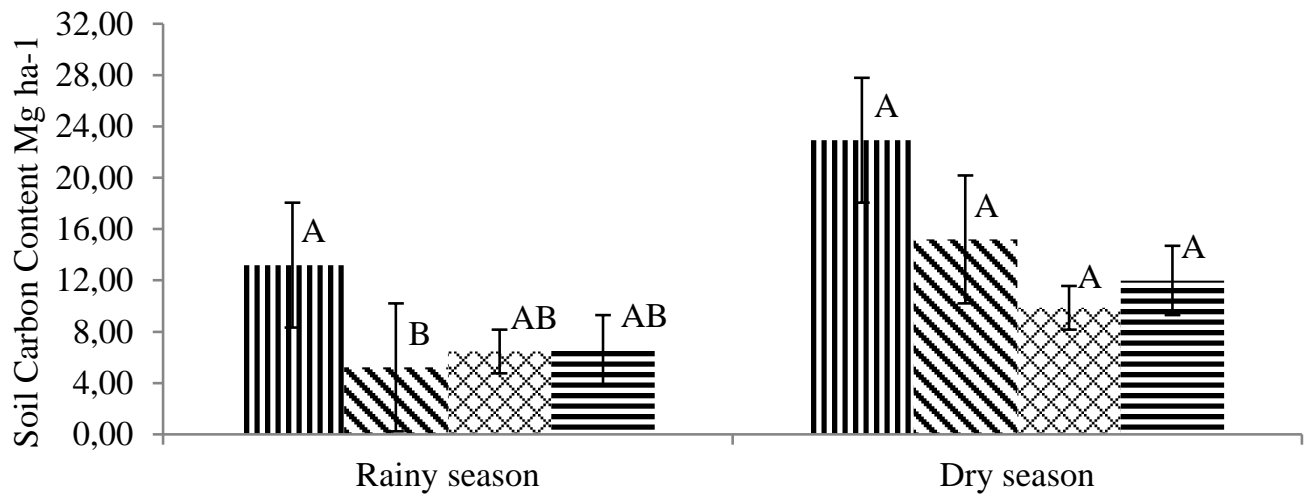

Figure 4. Soil carbon content $\left(\mathrm{Mg} \mathrm{ha}^{-1}\right)$ in preserved Caatinga area at different depths during rainy and dry seasons in the municipality of Várzea - PB.

Figura 4. Quantidade de Carbono no solo $\left(\mathrm{Mg} \mathrm{ha}^{-1}\right)$ em área de Caatinga Preservada em diferentes profundidades nas épocas chuvosa e seca no município de Várzea - PB.

Means followed by the same letter between the depths do not differ statistically from each other by the Tukey test at $5 \%$ probability, as well as the respective standard error bars. SMD: rainy season $=7.95$; dry season $=14.62$. 


\section{Soil carbon stock in different succession areas}

The values of the carbon stock found in the native pasture area (table 4), summing the values obtained in the depths $0-5 \mathrm{~cm}$ and $5-10 \mathrm{~cm}$ in the rainy season, it is found the carbon stock in the order of $28.81 \mathrm{Mg} \mathrm{ha}^{-1}$ and performing this same procedure for the dry season yields the carbon stock of $79.56 \mathrm{Mg} \mathrm{ha}^{-1}$.

Table 4. Soil carbon content $\left(\mathrm{Mg} \mathrm{ha}^{-1}\right)$ at different physiognomies and different depths during rainy and dry seasons in the municipality of Varzea-PB

Tabela 4. Estoque de carbono no solo $\left(\mathrm{Mg} \mathrm{ha}^{-1}\right)$ em diferentes fisionomias e em diferentes profundidades nas épocas chuvosa e seca no município de Várzea-PB

\begin{tabular}{|c|c|c|}
\hline \multicolumn{3}{|l|}{ Native Pasture Area } \\
\hline Depth & Rainy season & Dry season \\
\hline $0-5 \mathrm{~cm}$ & $13.30 \mathrm{a}$ & $50.75 \mathrm{a}$ \\
\hline $5-10 \mathrm{~cm}$ & $15.51 \mathrm{a}$ & $28.81 \mathrm{ab}$ \\
\hline $10-15 \mathrm{~cm}$ & $11.11 \mathrm{a}$ & $16.27 \mathrm{~b}$ \\
\hline $15-20 \mathrm{~cm}$ & $13.02 \mathrm{a}$ & $22.19 \mathrm{ab}$ \\
\hline Significative Minimum Difference & 26.83 & 28.81 \\
\hline Coefficient of Variation - $\%$ & 77.53 & 37.34 \\
\hline \multicolumn{3}{|l|}{ Initial Secondary Caatinga Area } \\
\hline Depth & Rainy season & Dry season \\
\hline $0-5 \mathrm{~cm}$ & $16.73 \mathrm{a}$ & $47.90 \mathrm{a}$ \\
\hline $5-10 \mathrm{~cm}$ & $14.65 \mathrm{a}$ & $33.45 \mathrm{a}$ \\
\hline $10-15 \mathrm{~cm}$ & $16.27 \mathrm{a}$ & $24.28 \mathrm{a}$ \\
\hline $15-20 \mathrm{~cm}$ & $10.96 \mathrm{a}$ & $29.52 \mathrm{a}$ \\
\hline Significative Minimum Difference & 22.90 & 53.90 \\
\hline Coefficient of Variation - \% & 59.78 & 61.00 \\
\hline \multicolumn{3}{|l|}{ Late Secondary Caatinga Area } \\
\hline Depth & Rainy season & Dry season \\
\hline $0-5 \mathrm{~cm}$ & $47.25 \mathrm{a}$ & $48.25 \mathrm{a}$ \\
\hline $5-10 \mathrm{~cm}$ & $32.82 \mathrm{a}$ & $38.05 \mathrm{a}$ \\
\hline $10-15 \mathrm{~cm}$ & $28.38 \mathrm{a}$ & $48.91 \mathrm{a}$ \\
\hline $15-20 \mathrm{~cm}$ & $23.58 \mathrm{a}$ & $39.68 \mathrm{a}$ \\
\hline Significative Minimum Difference & 37.24 & 43.38 \\
\hline Coefficient of Variation - \% & 37.25 & 37.93 \\
\hline \multicolumn{3}{|l|}{ Preserved Caatinga Area } \\
\hline Depth & Rainy season & Dry season \\
\hline $0-5 \mathrm{~cm}$ & $44.25 \mathrm{a}$ & $74.30 \mathrm{a}$ \\
\hline $5-10 \mathrm{~cm}$ & $19.50 \mathrm{~b}$ & $51.77 \mathrm{a}$ \\
\hline $10-15 \mathrm{~cm}$ & $21.28 \mathrm{ab}$ & $33.60 \mathrm{a}$ \\
\hline $15-20 \mathrm{~cm}$ & $22.91 \mathrm{ab}$ & $39.42 \mathrm{a}$ \\
\hline Significative average difference & 24.16 & 40.90 \\
\hline Coefficient of Variation - \% & 34.23 & 31.92 \\
\hline
\end{tabular}

Means followed by the same letter between the depths do not differ statistically from each other by the Tukey test at $5 \%$ probability, as well as the respective standard error bars.

\section{DISCUSSION}

In the year 2010, the rainfall in the region was below average, it was recorded for the municipality of Várzea-PB total volume of $550.5 \mathrm{~mm}$ (AESA, 2017). The rainy period considered in the present study was from January to June/2010, in which there was a rainfall of $451.3 \mathrm{~mm}$; on the other side, the dry period, that was from July to December/2010, the precipitated volume was of $99.2 \mathrm{~mm}$. It was verified in the analysis of variance (Table 2) that the data referring to the amounts of carbon in the soil presented significant differences regarding the factors of time, area of study and depth.

This differentiation indicates that the presence of carbon varies according to the soil depth and also according to the vegetal composition of the area; influencing through the contribution of organic matter in the soil and its decomposition, as well as the presence of microbial activity according to soil depth. It is known that humidity and temperature are factors that also affect the presence of carbon in the soil, characterized by the climatic seasonality of the region, however, it was not verified differences between the interaction of these factors.

The quantity and the stocks of carbon were higher in the dry season than in the rainy season in all studied areas, as can be seen in Table 3. The highest amounts of carbon in the soil are in the areas of Late Secondary Caatinga and Preserved Caatinga. The effect of seasonality on the quantities and average carbon stock was 
observed in three of the four areas studied. As for seasonality, it should be noted that the behavior of the environment is influenced by the climatic conditions of the region and that in the caatinga area, where this study was developed, the seasonality is well defined, with more intense precipitation occurrences ranging from 3 to 4 months, registering high temperatures for most of the year, which favors the water deficit in the soil, thus contributing to the susceptibility of degradation (Almeida et al., 2014). Thus, the high temperatures and the higher incidence of solar rays on the soil surface in areas with little or sparse vegetation can favor the oxidation of carbon in the soil, therefore modifying the stock balance.

It is probable that this higher concentration of carbon in the dry season is due to the death of the fine roots, mainly of the herbaceous stratum that does not support water deficit and is eliminated, being this a seasonal behavior in areas of caatinga. The absence of soil rotation, combined with the more efficient decomposition of the biomass present in the soil, results in a greater accumulation of carbon, evidencing that the soil under caatinga can be considered an efficient assimilator and accumulator of carbon. This behavior is confirmed by Salcedo and Sampaio (2008) and Martins et al. (2006), in which the authors affirm that the highest concentrations and stocks of carbon in the soil at the end of the dry period are due to leaf deposition, the end of the herbaceous cycle and death of fine roots, being these the main carbon inputs in the ground.

The total organic carbon stock in the soil (Table 3) follows the average soil carbon values in each area. In the less preserved areas, Native pasture in the rainy and dry seasons and the area of rainy Initial Secondary Caatinga in the rainy season, the stocks had been lesser and these results evidence that alterations in these areas, as the withdrawal of arboreal vegetation, soil rotation, grazing and burning had promoted deficit in the carbon supplies of these areas.

Lima et al. (2011) evaluating changes in the chemical characteristics, as well as in the supplies of carbon and nitrogen under agroforestry systems with different ages in the North of the State of Piauí, had also registered bigger carbon supply in the dry period in all the evaluated areas. The authors had observed that the supplies had been raised in the agroforestry systems and had correlated to the biggest amount of burlap accumulated in the ground in these systems, having improved its quality due to the interactions between the forest and agricultural components.

In the native pasture area (Figure 1), it was observed that in the rainy season there was no significant difference in the average carbon contents between the evaluated depths. However, in the dry season there was a significant difference in the carbon content, being the superficial layer the one with the highest presence of carbon content, with $14.03 \mathrm{Mg} \mathrm{ha}^{-1}$. According to Costa et al. (2009), the increase in carbon contents in soils under pasture may be more related to the quality of organic material to be degraded than to the amount of material produced in different environments, which can guarantee greater permanence of carbon in a system in detriment of the other.

As for the areas of Initial Secondary and Late Secondary Caatinga there is also a greater tendency that the greatest amount of carbon is in the superficial layer $0-5 \mathrm{~cm}$ and it can be attributed to the presence of the deposited material on the surface of the soil, since in the areas of Initial Secondary and Late Secondary Caatinga there is the occurrence of herbaceous species of short cycle, as well as tree species of deciduous behavior that contribute to the increase of accumulated biomass.

The area of Preserved Caatinga presented in the dry season the highest average levels of carbon in all depths in relation to the rainy season; and in relation to the other studied areas, since it is an area that has not been antropic for several years, it allowed the soil to perform its function as a carbon sink.

\section{Soil carbon stock in different succession areas}

Regarding the soil carbon stock in the Preserved Caatinga area (Table 4), a statistical difference was observed between the values obtained at different depths only in the rainy season. It was in the $0-5 \mathrm{~cm}$ layer that the largest carbon stock was recorded in both seasons (rainy and dry). In addition, in the other areas, the dry season presents higher values in the carbon stock, indicating that in the preserved area the formation of the burlap is more intense and varied due to the more heterogeneous formation of the area and the longer vegetation cover. Corroborating Rozane et al. (2001), the authors reported that the greatest carbon accumulation is found in the topsoil, probably due to the greater amount of organic residues on the soil surface.

Martins et al. (2010) measured the carbon stock in area of caatinga in the municipality of Floresta in Pernambuco, of 21,682 $\mathrm{Mg} \mathrm{ha}^{-1}$ in dry period and 23,164 $\mathrm{Mg} \mathrm{ha}^{-1}$ in the rainy period in preserved area, being these values inferior to the ones found in area of Late Secondary Caatinga and area of Preserved Caatinga.

The values of the carbon stock found in the native pasture area (table 4), summing the values obtained in the depths $0-5 \mathrm{~cm}$ and $5-10 \mathrm{~cm}$ in the rainy season, it is found the carbon stock in the order of $28.81 \mathrm{Mg}$ ha -1 and performing this same procedure for the dry season yields the carbon stock of $79.56 \mathrm{Mg}$ ha -1 . It should be noted that the artifice was made to compare the data obtained in this research with the reported ones by Martins et al. (2010) in degraded environment in the semi-arid Pernambucano, that obtained in the rainy season $14.004 \mathrm{Mg}$ ha 1 and dry period $9.669 \mathrm{Mg}$ ha -1 of carbon in the soil, values lower than those obtained in the native pasture area, 
which among those evaluated was the one most submitted to anthropic interference. Sampaio and Costa (2011) report an average carbon stock in preserved caatinga in the order of $36 \mathrm{Mg} \mathrm{ha}^{-1}$ carbon in the $0-20 \mathrm{~cm}$ layer, a value lower than those recorded in the present study in the two seasons. Another important observation in the present study was the sharp reduction of the stock with the increase in depth, especially in the dry season, where the reduction in the surface layer stock to the last layer evaluated $(15-20 \mathrm{~cm})$ was $39 \%$.

In relation to the carbon stock in the area of Initial and Late Secondary Caatinga, it was observed in table 4 that the values are statistically similar. The values obtained in the two seasons and depths in the Late Secondary Caatinga area surpassed those recorded in the Initial Secondary Caatinga, however, it was observed that in this area the values in the different seasons are more approximate. This indicates, probably, that when the environment recovers, there is a balance between inputs and outputs, maintaining a certain constancy in the carbon stock.

Regarding the soil carbon stock in the Preserved Caatinga area (Table 4), a statistical difference was observed between the values obtained at different depths only in the rainy season. It was in the 0-5 cm layer that the largest carbon stock was recorded in both seasons (rainy and dry). According to Sampaio and Costa (2011), there is evidence that in areas of caatinga with better cover of shrub and tree species there is a greater stock of biomass and that in pasture areas there is, consequently, less biomass, being the carbon stock behavior similar to this distribution of biomass, and, then, having higher stock in more preserved areas.

The results of the present study in the Preserved Caatinga area show that the presence of older or stable vegetation allows the carbon flux in the soil to occur in a balanced way, with a higher biota action with low energy requirement and, consequently, low losses of $\mathrm{CO}_{2}$, allowing the maintenance of higher levels in depth, making this environment a great carbon assimilator. Thus, it is evident that anthropic interference tends to reduce the carbon stock in the soil and that the removal of the native vegetation deprives the forests function as a carbon sink. These results corroborate with Menezes et al. (2012), which consider the recurrent systems of cutting and burning vegetation of the caatinga as a contributing factor for significant losses of carbon in the soil.

The results obtained allow us to know how areas of caatinga in different successional stages and anthropic area maintains the carbon stocks in the soil seasonally, with consequent reduction in the emission of the $\mathrm{CO}_{2}$. This information is important in the contribution of the construction of a database on the potential of the Caatinga biome to reduce the concentration of greenhouse gases (GHGs) to the atmosphere and, consequently, to propose practices of management and preservation of areas in the northeastern semiarid region, valuing these environments as carbon sinks.

\section{CONCLUSIONS}

- The highest concentrations of organic carbon were found in the Preserved Caatinga area;

- Regardless of the successional stage, the carbon concentrations showed seasonal variation, registering the highest values in the dry season, being these data an important indication that the caatinga is efficient in accumulating carbon in the period of water deficit.

- The highest content and carbon stock occurred in the superficial layer $(0-5 \mathrm{~cm})$, with decreasing values as the depth increases.

\section{REFERENCES}

AGÊNCIA EXECUTIVA DE GESTÃo DAS ÁGUAS DO ESTADO DA PARAÍBA (AESA). http://www.aesa.pb.gov.br/aesa-website/meteorologia-chuvas. Acesso em maio de 2017.

AlCÂNTARA NETO, F.; LEITE, L. F. C.; ARNHOLD, E.; MACIEL, G. A.; CARNEIRO, R. F. V. Compartimentos de carbono em Latossolo Vermelho sob cultivo de Eucalipto e fitofisionomias de Cerrado. Revista Brasileira Ciência do Solo, Viçosa, v. 35, n. 3, p. 849-856, 2011.

ALMEIDA, E. M.; CAMPELO JÚNIOR, J. H.; FINGER, Z. Determinação do estoque de carbono em teca (Tectona grandis L. F.) em diferentes idades. Ciência Florestal, Santa Maria, v. 20, n. 4, p. 559-568, 2010.

ALMEIDA, H. A.; AGUIAR, D. B.; SILVA, J. N.; DAMASECENO, J. Indicadores hídricos do núcleo de desertificação da microrregião do Seridó Ocidental da Paraíba. Revista Brasileira de Geografia Física, v. 7 , n. 5 (Número Especial- VIWMCRHPE), p. 784 - 797, 2014.

ALVARES, C. A.; STAPE, J. L.; SENTELHAS, P. C.; GONÇALVES, J. L. M.; SPAROVEK, G. Köppen's climate classification map for Brazil. Meteorologische Zeitschrift, Stuttgart, v. 22, n. 6, p. 711-728, 2014. 
COSTA, O. V.; CANTARUTTI, R. B.; FONTES, L. E. F.; COSTA, L. M.; NACIF, P. G. S.; FARIA, J. C. Estoque de carbono do solo sob pastagem em área de tabuleiro costeiro no Sul da Bahia. Revista Brasileira Ciência do Solo, Viçosa, v. 33, n. 5, p. 1137-1145, 2009.

EMBRAPA. Centro Nacional de Pesquisa de Solos. Sistema Brasileiro de Classificação de Solos. Rio de Janeiro: Embrapa/CNPS, 2. ed. 2013. 353p.

GATTO, A.; BARROS, N. F.; NOVAIS, R. F.; SILVA, I. R.; LEITE, H. G.; LEITE, F. P.; VILLANI, E. M. A. Estoques de carbono no solo e na biomassa em plantações de eucalipto. Revista Brasileira Ciência do Solo, Viçosa, v. 34, n. 4, p. 1069-1079, 2010.

LAL, R. Soil carbon dynamics in cropland and rangeland. Environmental Pollution, Ohio, v. 116, n. 3 p. 353 $362,2002$.

LIMA, S. S.; LEITE, L. F. C.; OLIVEIRA, F. C.; COSTA, D. B. Atributos químicos e estoques de carbono e nitrogênio em argissolo vermelho-amarelo sob sistemas agroflorestais e agricultura de corte e queima no norte do Piauí. Revista Árvore, Viçosa, v. 35, n. 1, p. 51-6, 2011.

MARTINS, C. M.; GALINDO, I. C. L.; SOUZA, E. R.; POROCA, H. A. Atributos químicos e microbianos do solo de Áreas em processo de desertificação no Semiárido de Pernambuco. Revista Brasileira Ciência Solo, Viçosa, v. 34, n. 6, p. 1883-1890, 2010.

MENEZES, R. S. C.; SAMPAIO, E. V. S. B.; GIONGO, V.; PÉREZ-MARIN, A. M. Biogeochemical cycling in terrestrial ecosystems of the Caatinga Biome. Brazilian Journal of Biology, São Carlos, v. 72, n. 3, p. 643-653, 2012 .

NUNES, L. A. P. L.; ARAÚJO FILHO, J. A.; HOLANDA JÚNIOR, E. V.; MENEZES, R. Í. Q. Impacto da queimada e de enleiramento de resíduos orgânicos em atributos biológicos de solo sob Caatinga no semiárido nordestino. Revista Caatinga, Mossoró, v. 22, n.1, p. 131-140, 2009.

RIOS, L. C.; CONCEIÇÃO, M.; PÉREZ, D. V.; ARAÚJO, W. S. Estoque de carbono e caracterização de substâncias húmicas em solos sob seringais cultivados e vegetação natural. In: ALVARENGA, A. P.; CARMO, C. A. F. S. Sequestro em seringais de cultivo e na vegetação natural: quantificação em seringas de cultivo e na vegetação natural. Viçosa: 2006, 352 p.

ROZANE, D. E.; CENTURION, J. F.; ROMUALDO, L. M.; TANIGUCHI, C. A. K.; TRABUCO, M.; ALVES, A. U. Estoque de carbono e estabilidade de agregados de um latossolo vermelho distrófico, sob diferentes manejos. Bioscience Journal, Uberlândia, v. 26, n. 1, p. 24-32, 2010.

SALCEDO I. H.; SAMPAIO E. V. S. B. Matéria orgânica do solo no bioma caatinga. In: SANTOS, G. S.; SILVA, L. S.; CANELLAS, L. P.; CAMARGO, F. A. O. (eds). Fundamentos da matéria orgânica do solo: ecossistemas tropicais e subtropicais. Porto Alegre: Metrópole, 2008, 654 p.

SAMPAIO, E. V. S. B.; COSTA, T. L. Estoques e Fluxos de Carbono no Semi-Árido Nordestino: Estimativas Preliminares. Revista Brasileira de Geografia Física, Recife, v. 4, n. 6, p.1275-1291, 2011.

SILVA, F. A. S. E.; AZEVEDO, C. A. V. Software de assistência a estatística. Versão beta 7.6. 2012.

SILVA, R. F.; SOARES, C. P. B.; JACOVINE, L. A. G.; SILVA, M. L.; LEITE, H. G.; SILVA, G. F. Projeção do estoque de carbono e análise da geração de créditos em povoamentos de eucalipto. Revista Árvore, Viçosa, v. 32, n. 6, p. 979-992, 2008.

SILVEIRA, P.; KOEHLER, H. S.; SANQUETTA, C. R.; ARCE, J. E. O estado da arte na estimativa de biomassa e carbono em formações florestais. Floresta, Curitiba, v. 38, n. 1, p. 185-206, 2008. 